\title{
Using estuarine landscape structure to model distribution patterns in nekton communities and in juveniles of fishery species
}

\author{
Shannon D. Whaley ${ }^{1, *}$, James J. Burd Jr. ${ }^{1}$, Bradley A. Robertson ${ }^{1,2}$ \\ ${ }^{1}$ Fish and Wildlife Conservation Commission, Florida Fish and Wildlife Research Institute, 100 8th Avenue SE, \\ St. Petersburg, Florida 33701, USA \\ ${ }^{2}$ Present address: Sarasota County Natural Resources, 1301 Cattlemen Road, Sarasota, Florida 34232, USA
}

\begin{abstract}
Spatial relationships between distribution patterns of many species and vegetated habitats over multiple scales have been used in terrestrial ecosystems to help identify and map important areas for conservation and management. This approach is not widely used in characterizing habitat use of nekton species in estuaries, but it has great potential because these systems contain fairly discrete vegetated habitat types, and the distribution of nekton species can be influenced by the spatial arrangement of habitat. We examined the spatial relationships between estuarine habitats and nekton species to help map estuarine nekton communities for use in conservation planning. Using a Geographic Information System (GIS), we measured area $\left(\mathrm{m}^{2}\right)$ and edge density $\left(\mathrm{m} \mathrm{km}^{-2}\right)$ of estuarine habitats over multiple scales in Charlotte Harbor, Florida (USA). We used redundancy analysis (RDA) to examine spatial patterns of nekton community composition, habitat, and local habitat characteristics. RDA revealed that spatial patterns in nekton community composition were most highly correlated with distance from the nearest pass to the Gulf of Mexico ( $\mathrm{r}=-0.97)$ and with salinity $(r=0.94)$ and area of continuous seagrass habitat $(r=0.91)$. We used GIS maps of 2 variables (distance from the nearest pass and area of continuous seagrass habitat) to model spatial patterns in nekton community composition and the distribution of several juveniles of fishery species (red drum Sciaenops ocellatus, gray snapper Lutjanus griseus, lane snapper L. synagris, sand seatrout Cynoscion arenarius, and spotted seatrout C. nebulosus). The results suggest that incorporating measures of habitat area (over multiple scales) and spatial position into spatial models of nekton distribution is useful in conservation and management planning.
\end{abstract}

KEY WORDS: Estuary $\cdot$ Landscape structure $\cdot$ Broad scale $\cdot$ Spatial patterns $\cdot$ Geographic Information Systems $\cdot$ Species frequency of occurrence $\cdot$ Species distribution $\cdot$ Species richness

- Resale or republication not permitted without written consent of the publisher

\section{INTRODUCTION}

Models predicting species distributions over large areas (10s to 1000s of $\mathrm{km}$ ) based on habitat maps have helped to describe and map important areas for conservation and management (mainly in terrestrial ecosystems, e.g. Murphy \& Noon 1992, Breininger et al. 1995). Much effort has focused on predictive spatial modeling of individual species in both terrestrial ecosystems (see review by Guisan \& Zimmerman 2000) and estuaries (e.g. Brown et al. 2000, Jensen et al.
2005). However, conservation goals can often include preservation of biodiversity, ecosystem processes such as productivity, as well as habitats used by multiple rare or economically important species (see reviews by Margules \& Pressey 2000, Roberts et al. 2003). In these cases, a community-based modeling approach may be a practical alternative to modeling many species separately (e.g. Borcard \& Legendre 1994, Carbonell et al. 2003, Araujo et al. 2004). In addition, communitybased analyses provide information regarding species co-occurrences that can be useful in establishing spe- 
cies-environment relationships used in predictive modeling (ter Braak 1995, Guisan et al. 1999).

In estuaries, nekton communities represent a key trophic link between primary production and higher trophic levels, including many larger fishes and wading birds. Therefore, nekton community structure may be a useful indicator of ecosystem condition and processes (Deegan et al. 1997), as well as of overall estuarine biodiversity (Ward et al. 1999). In addition, estuarine nekton communities often include juveniles of numerous fishery species that have economic importance as adults. Therefore, spatial descriptions of nekton communities may be of particular interest in monitoring ecosystem processes or prioritizing estuarine areas for conservation and management.

Many estuarine nekton species use salt marshes, mangroves, and seagrass beds as foraging habitats or refugia from predation (Beck et al. 2001 and references therein). Habitat use by nekton can be related to the configuration, amount, or location of estuarine habitats at multiple spatial scales (Pittman et al. 2004 and references therein). Local-scale (meters to 10 s of meters) configuration (e.g. edge:area ratio) of salt marshes (Kneib 2003, Minello et al. 2003), mangroves (Smith \& Hindell 2005 and references therein) and seagrass beds (McNeill \& Fairweather 1993, Hovel \& Lipcius 2001) can influence habitat use by nekton species. Within a region of an embayment or estuary, the spatial configuration of multiple habitat types (e.g. seagrass and wetland patches, or seagrass patches and coral reefs) can also affect habitat use as well as abundance, growth, and biodiversity of nekton (e.g. Parrish 1989, Irlandi \& Crawford 1997, Pittman et al. 2004, Skilleter et al. 2005). On a broader scale (10s to 1000 s of $\mathrm{km}$ ), the location of a particular habitat relative to the nearest connection to the marine environment (e.g. estuary mouth or pass) can influence habitat use by nekton species and assemblages (e.g. Bell et al. 1988, Hannan \& Williams 1998, Pérez-Castañeda \& Defeo 2004). At these broad scales, only a few studies (e.g. Ward et al. 1999, Pittman et al. 2004) have related distribution patterns of nekton communities to configuration, amount, or location of multiple estuarine habitat types mapped from aerial photography. Ward et al. (1999) found positive relationships between the occurrence of mapped mangrove, salt marsh, and seagrass habitats and relatively high numbers of nekton taxa (species richness). Pittman et al. (2004) found positive correlations between area of continuous seagrass and high relative densities and diversity of nekton communities. Although these studies were conducted in 2 embayments along the eastern coast of Australia, similar relationships between mapped estuarine habitats and nekton community structure may also occur elsewhere as a result of strong associations between these habitats and many nekton species. These spatial relationships may help to describe and map distributions of nekton communities and species, including juveniles of fishery species.

This study investigated relationships between estuarine landscape structure, defined as the amount and spatial arrangement of habitat types (salt marshes, mangroves, and seagrass beds), and the spatial distribution of nekton communities and juveniles of several fishery species in shallow areas of Charlotte Harbor, Florida (USA), a subtropical estuary. The objectives of the study comprised: (1) quantifying estuarine landscape structure at multiple spatial scales using available habitat maps, (2) examining relationships between estuarine landscape structure and spatial distribution of nekton communities to identify the most influential spatial predictors and spatial scale, and (3) using identified predictors to develop spatial distribution models for the nekton community and several juveniles of several fishery species (red drum $S_{C i}$ aenops ocellatus, gray snapper Lutjanus griseus, lane snapper L. synagris, sand seatrout Cynoscion arenarius, and spotted seatrout C. nebulosus). Relationships between a single or a small number of environmental variables and a single species are often examined in isolation. Ecosystems, however, are complicated by interactions among numerous species and environmental variables, and these characteristics and components of ecosystems cannot easily be isolated, especially across broad spatial scales. Thus, the general approach in this study was not to isolate the most important variable influencing community structure, but to use spatial structuring common to multiple variables and nekton species to predict general nekton distribution patterns across the estuarine ecosystem.

\section{MATERIALS AND METHODS}

Study area. Charlotte Harbor (Fig. 1), located on Florida's peninsular Gulf coast, is one of the largest estuaries in the state, with an open water area of approximately $700 \mathrm{~km}^{2}$ (Harris et al. 1983). Seagrass (principally shoal grass Halodule wrightii, turtle grass Thalassia testudinum, and manatee grass Syringodium filiforme) is common in shallow-water areas of Charlotte Harbor, with seagrass beds generally becoming more abundant with larger more continuous patches near the mouth of the estuary. Natural shorelines of the estuary are dominated by mangroves (red mangrove Rhizophora mangle, black mangrove Avicennia germinans, white mangrove Laguncularia racemosa) mainly in the estuary proper. Salt marshes (primarily black needlerush Juncus roemerianus) generally occur in brackish portions of the rivers flowing into the estuary 


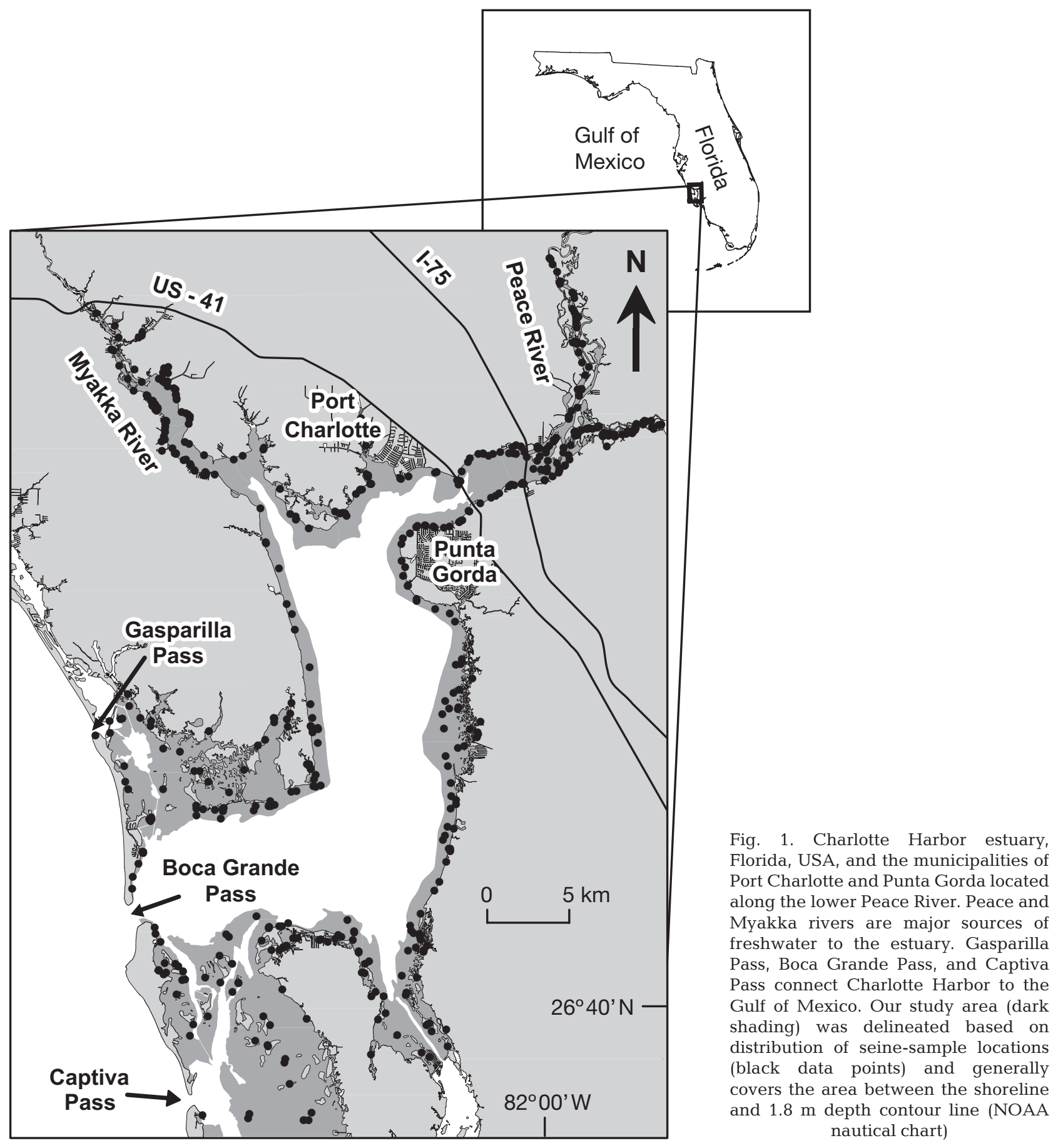

and landward of the mangrove forests in the estuary proper. The major freshwater sources for Charlotte Harbor are the Peace and Myakka rivers, which flow into the harbor from the north. Sediments in the estuary proper are generally characterized as sand, while sediments in the rivers are typically mud. The towns of Punta Gorda and Port Charlotte are located opposite each other along the lower portion of the Peace River (Fig. 1), and these municipalities are protected by sea- wall and riprap shorelines that have replaced natural shoreline vegetation. Hardened shorelines also occur along the lower portion of the Myakka River. Natural mangrove shorelines in most of the estuary are protected as Aquatic Preserves by the Florida Department of Environmental Protection. Charlotte Harbor is connected to the Gulf of Mexico by a major inlet, Boca Grande Pass, and several smaller passes through the barrier islands (Fig. 1). 
Nekton data collection. Nekton data were collected on a monthly basis during daylight hours in the fall (defined as September 1 to November 30) from 1997 to 2000 by the State of Florida's Fisheries-Independent Monitoring Program (FIM; Florida Fish and Wildlife Conservation Commission, Fish and Wildlife Research Institute). Nekton was collected with a $21.3 \mathrm{~m}$ centerbag seine ( $3.2 \mathrm{~mm}$ stretched mesh) that targeted smaller fishes (generally 15 to $100 \mathrm{~mm}$ standard length) and was deployed in water depths of $\leq 1.8 \mathrm{~m}$ (rivers) or $\leq 1.5 \mathrm{~m}$ (estuary). Seine samples were collected monthly at sites selected via a stratified random sampling design. In this design, the Charlotte Harbor study area was divided into several large spatial zones. Each zone was divided into 1 min latitude $\times 1$ min longitude grid cells, and these were randomly selected each month for sampling. Each selected grid cell was subdivided into 100 micro-grid cells and sampling sites were selected randomly from these micro-grid cells. The $21.3 \mathrm{~m}$ seines were deployed in 3 different ways, depending on site location. Areas away ( $>5 \mathrm{~m}$ ) from any shoreline were stratified based on presence or absence of submerged aquatic vegetation. The number of samples in each category reflected the proportional area of each habitat type that could be sampled with the seine (6 to 10 samples $\mathrm{mo}^{-1}$ in $>10 \%$ vegetation cover, 2 to 6 samples $\mathrm{mo}^{-1}$ collected in $<10 \%$ vegetation cover, 12 samples $\mathrm{mo}^{-1}$ total). These offshore areas were sampled by pulling the seine for $9.1 \mathrm{~m}$; the 2 seine poles were then brought together, and the wings of the net were pulled across a pivot-pole to concentrate the sample in the bag (sampling area $=$ $140 \mathrm{~m}^{2}$ ). In 1997 only, the shoreline was sampled by

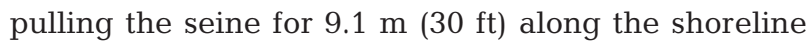
and then hauling it onto shore (14 to 15 samples $\mathrm{mo}^{-1}$; sampling area $=338 \mathrm{~m}^{2}$ ). Beginning in 1998, the same deployment strategy used for offshore areas was used to sample along the estuarine shoreline (12 samples $\mathrm{mo}^{-1}$ ). To sample the steep banks of the Peace and Myakka rivers, seines were deployed by boat in a semicircular pattern along the shoreline, then pulled by hand onshore (sampling area $=68 \mathrm{~m}^{2}$ ); 8 samples $\mathrm{mo}^{-1}$ were collected in the riverine areas during 1997 to 2000 , and these samples were stratified by the presence or absence of overhanging shoreline vegetation (primarily mangroves). In conjunction with a special study during 1997 to 1998, 22 additional seine samples were collected each month in the rivers. These sampling sites were randomly selected each month from 11 zones that were spatially stratified along the salinity gradient.

All fish species and invertebrates of commercial importance (e.g. pink shrimp Farfantepenaeus duorarum and blue crab Callinectes sapidus) were identified to the lowest feasible taxonomic level (usually to species) in the field. However, Eucinostomus spp. and Gobiosoma spp. were identified to genus level when $<40 \mathrm{~mm}$ standard length (SL) and $<20 \mathrm{~mm} \mathrm{SL}$, respectively. For each species collected on a given sampling trip, a representative sample (3 specimens) was retained to verify field identifications in the laboratory. Salinity (ppt), water temperature $\left({ }^{\circ} \mathrm{C}\right)$, and dissolved oxygen $\left(\mathrm{mg} \mathrm{l}^{-1}\right)$ were recorded concurrently with each seine sample using a Hydrolab ${ }^{\circledR}$ multiprobe. The percentage of seagrass cover was estimated visually over the area swept by each seine. Water depth was measured at the seine's center bag at the beginning of deployment. Locations of nekton sampling sites were recorded in the field via GPS, and we used these locations to import nekton and environmental data into a GIS database.

Estuarine landscape structure. We used mostly existing GIS coverages of mangroves, salt marshes, and seagrass beds to examine estuarine landscape structure across Charlotte Harbor. We extracted mangrove and salt marsh habitat data from a digital land use and land cover data set for the Southwest Florida Water Management District (SWFWMD). This data set was created by photointerpreting 1:12000-scale United States Geological Survey color infrared (CIR) digital orthophoto quarter quadrangle (DOQQs) aerial images taken in 1999 and 2000. Photointerpretation was based on Florida Department of Transportation's Florida Land Use and Cover Classification System (FDOT 1999). Photointerpreters used a minimum mapping unit (MMU) of 0.5 acres $(0.2 \mathrm{ha})$ for mangrove and salt marsh land use/land cover types. Although map accuracy was not assessed specifically for the 1999 version of the land use and land cover data set, overall map accuracy for a previous version (1990) was estimated at $95 \%$ based on 673 random locations verified independently from photography (72 locations were also field verified, Dicks \& Lo 1990). For the southern portion of our study area, where similar land use/land cover data were not available, we delineated mangrove and salt marsh habitats using 1:12000-scale 1999/2000 USGS CIR DOQQ images with $1 \mathrm{~m}$ pixel resolution. Map accuracy for this data set was not formally quantified, but was reviewed by independent photointerpreters. For seagrass habitat, we merged a map of seagrass habitat (SWFWMD) covering the northern part of Charlotte Harbor with a map covering the southern portion (South Florida Water Management District). Both data sets were derived by photointerpreting 1:24 000-scale natural color aerial photographs taken on December 26, 1999. General procedures were similar for mapping seagrass in both areas, however; photointerpreters used a MMU of 0.5 acre (0.2 ha) for the northern data set, and a 0.25 acre ( $0.1 \mathrm{ha}$ ) MMU for the southern data set. Seagrass was classified into 2 classes: discontinuous 
seagrass (seagrass coverage estimated from 10 to $75-85 \%$ ) and continuous seagrass (seagrass coverage >75-85\%). For map accuracy assessment, the discontinuous and continuous seagrass classes were combined. The overall map accuracy was estimated at $96 \%$ based on an independent data set of 55 ground samples selected at random locations.

We calculated the area $\left(\mathrm{m}^{2}\right)$ of mangrove, salt marsh, discontinuous seagrass, continuous seagrass, and combined seagrass (discontinuous and continuous) within circular zones of increasing spatial extent (radii $=100$, 200, 400, 800 and $1600 \mathrm{~m}$ ) around each fish sampling site. Because intertidal wetland habitats are rarely entirely inundated, wetland habitat area calculations provided an estimate of the maximum amount of wetland habitat available to fishes at the highest tide levels. To estimate the minimum amount of wetland habitat (that is usually available to nekton at high tide), we calculated the amount of wetland-open-water edges around each sampling site. Wetland-openwater edges were considered to be those boundaries between a wetland habitat (mangrove or salt marsh) and a frequently inundated habitat, such as tidal flats, open water, or submerged aquatic vegetation. Wetland-upland edges were therefore excluded from the edgedensity calculations. Length of salt marshopen-water edges and mangrove-openwater edges were summed separately within the circular zones used for area calculations, and then divided by area (edge density $=\mathrm{m} \mathrm{km}^{-2}$ ). To examine potential relationships between the connection to the marine environment and nekton community composition, we also calculated the distance (m) from each sampling site to the nearest pass to the Gulf of Mexico using the cost-distance function provided in the ArcGIS software package (ESRI), using the shoreline as a barrier. Habitat area and edge density metric values at each FIM sample location were log-transformed as $\ln (x+1)$, and then associated with fieldcollected environmental data for subsequent analysis. In addition, habitat area, edge density, and distance metrics were calculated for $100 \mathrm{~m}^{2}$ grid cells within the entire study area in the same way as for the sampling site locations. These calculations resulted in a series of continuous grid surfaces representing each metric value across the analysis area, and a subset of these grids was used in subsequent spatial modeling. We performed all GIS data preparation and analyses using ArcInfo and
ArcGIS with the Spatial Analyst extension (ESRI). Geographic analyses were performed in the UTM projection, Zone 17 North (m) using the NAD83 datum. All spatial modeling was constrained to the area between the $1.8 \mathrm{~m}$ (6 ft) depth contour line (NOAA digital nautical chart) and the shoreline (Fig. 1) because seines could only be deployed in shallow waters $(<1.8 \mathrm{~m}$ depth). Shallow canals and several isolated sand bars, as well as numerous small creeks and intertidal rivulets along the shoreline of Charlotte Harbor were also excluded, because these areas were not sampled or were sampled infrequently. The area remaining in the analysis represented approximately $40 \%$ of the total open-water area of Charlotte Harbor.

Community composition analysis. The steps followed in the nekton community analysis and subsequent spatial modeling are outlined in a flowchart (Fig. 2). We performed redundancy analysis (RDA) using CANOCO ${ }^{\mathrm{TM}}$ Version 4.5 (ter Braak \& Smilauer 2002) to examine estuary-wide relationships between nekton species composition, estuarine landscape structure, and local environmental conditions measured at

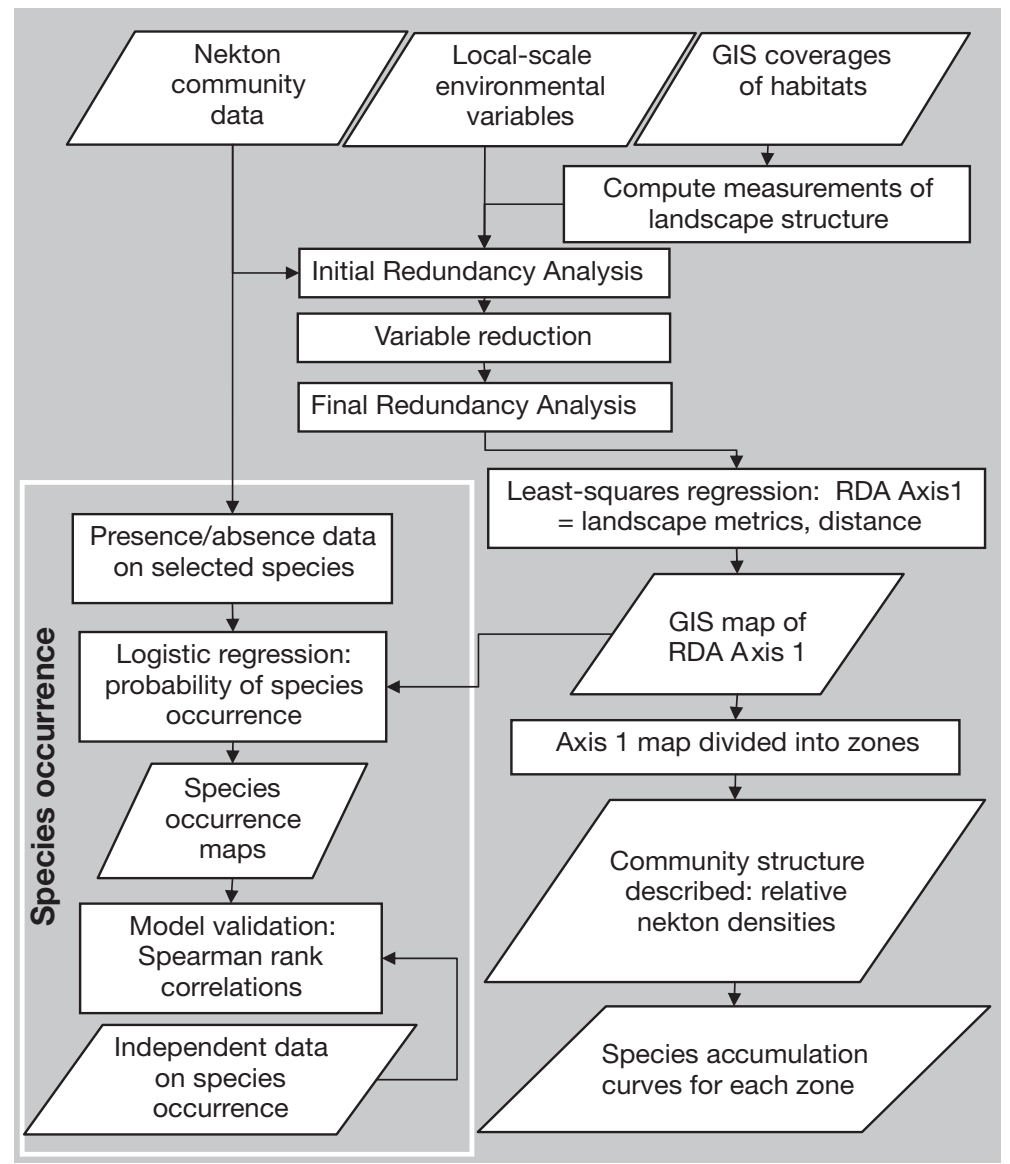

Fig. 2. Community analysis and spatial modeling of the nekton community and of individual species. Rectangles indicate a process and parallelograms indicate data input or output. GIS = Geographic Information System, RDA = redundancy analysis 
the sampling site. Prior to analysis, $25 \%$ of the sampling data (131 samples) were randomly selected (numbers were generated randomly at www.random. org/) and set aside as an independent data set to be used for model validation. For the remaining 392 sample locations, we estimated densities (ind. per $100 \mathrm{~m}^{2}$ area swept by seine) for each of 70 taxa. We then transformed taxon densities using the chord transformation to prevent the many rare species from excessively influencing the RDA analyses (see Legendre \& Gallagher 2001). The initial RDA included measures of habitat area $\left(\mathrm{m}^{2}\right)$ and edge densities $\left(\mathrm{m} \mathrm{km}^{-2}\right)$ for salt marsh, mangrove, continuous seagrass, discontinuous seagrass, and all seagrass combined (at 5 scales: 100 to $1600 \mathrm{~m}$ radius), spatial location relative to nearest connection to the Gulf (major inlet or smaller pass), and local-scale environmental variables - day of the year, salinity, water temperature $\left({ }^{\circ} \mathrm{C}\right)$, water depth $(\mathrm{m})$, estimated seagrass coverage $(\%)$, and dissolved oxygen $\left(\mathrm{mg} \mathrm{l}^{-1}\right)$ at the sampling site. Within the RDA procedure, all environmental and habitat measurements were standardized to a mean of zero and a variance of 1 to account for different units of measurements. RDA identified a number of orthogonal synthetic gradients, called RDA axes, that were most closely related to community structure (species composition) and were constrained to be linear combinations of the environmental and habitat variables (ter Braak 1995). Axes that were significantly related to nekton community structure $(\mathrm{p}<0.001)$ were identified using Monte Carlo tests (1000 permutations). To reduce the number of variables in the final RDA community model, we retained those variables that were highly correlated $(r \geq 80 \%)$ with each of the significant axes in the initial RDA. When no variables met this criterion for a significant axis, we retained the variable with the highest correlation with the axis.

RDA Axis 1 was modeled in a GIS to describe spatial structure in the nekton community across the study area. A multiple regression (least-squares) was developed with estuarine landscape structure and distance measures highly correlated to RDA Axis 1 scores using JMP v.5 (SAS Institute 2002). This model was then recalculated in the GIS (Raster Calculator function, Spatial Analyst extension, ArcMap 8, ESRI) using grids representing the model's input variables. Mapping RDA Axis 1 allowed us to project the nekton community ordination across geographic space. The analysis area was then divided into 4 spatial zones based on ranges of RDA Axis 1 scores (representing similarity in species composition) to concisely describe spatial patterns in estuarine landscape structure, community composition, and overall nekton density for samples collected in each zone. We also used the total number of species as a measure of diversity in each spatial zone. Because sampling area and effort in each zone differed, we first examined whether the sampling effort was adequate to allow general descriptions of the number of those species susceptible to seine capture. We plotted species-accumulation curves for each zone which illustrated the number of new species observed through time with increasing sampling effort (measured in $\mathrm{m}^{2}$ cumulative area sampled).

Individual species-distribution models. We used RDA Axis 1 as a predictor to model the probability of occurrence for juveniles (defined here as those effectively caught by the seine, generally 15 to $100 \mathrm{~mm} \mathrm{SL}$ ) of 5 fishery species (red drum Sciaenops ocellatus, gray snapper Lutjanus griseus, lane snapper L. synagris, sand seatrout Cynoscion arenarius, and spotted seatrout C. nebulosus) across the analysis area. After converting species densities in all samples into species presence or absence, we modeled probability of species occurrence using logistic regression, which is commonly used to relate a binary response variable (e.g. species presence/absence) to explanatory or predictor variables (Hosmer \& Lemeshow 2000). Spatially explicit logistic models were limited by those predictor variables (RDA Axis 1) that could be represented spatially in a GIS. In a stepwise procedure, linear and quadratic forms of RDA Axis 1 were evaluated based on the Wald test to derive a reduced model with only significant variables $(p<0.05)$. Goodness-of-fit for the overall model was tested using the likelihood ratio test $(p<0.05)$ and the Hosmer-Lemeshow test $(p>0.05$, Hosmer \& Lemeshow 2000). We used the percent reduction in the Akaike Information Criterion (AIC) from an intercept-only model to the final model as a measure of how well the model fit the data. Logistic models were developed for each species using S-Plus 6 (Insightful Corporation), and were implemented in GIS using the Raster Calculator function within Arc Map 8 GIS software (Spatial Analyst extension, ESRI) to map predicted probability of species occurrence across the study area. We then divided the range of predicted probabilities into 5 equal-interval probability classes to map general spatial trends in species probability of occurrence. Predictive performance of species occurrence models is rarely evaluated using independent data (Olden et al. 2002). To test the predictive ability of the models, we grouped the 131 independent observations on species presence or absence into deciles along values of the model predictor, RDA Axis 1. This allowed an equal number of observations (13) per group, and converted species presence or absence observations into a continuous variable, frequency of species occurrence per group. We used Spearman rank correlation analysis to measure the concordance between observed frequency of species occurrence in the independent data and model predictions (average probability of occurrence). Model predictions were considered successful (validated) when $\mathrm{p}<0.05$. 


\section{RESULTS}

\section{Gradients influencing nekton community structure}

Permutation tests showed that all 4 axes identified in the final RDA were significantly related to nekton community structure $(p<0.001)$. The first axis (RDA Axis 1) represented $57 \%$ of the total variation in nekton community composition explained in the analysis (Table 1). This axis represented a broad-scale spatial gradient from the tidally influenced freshwater and low-salinity areas of the Peace and Myakka rivers, where salt marsh habitat was relatively common, to areas near the passes to the Gulf, where continuous seagrass habitat was common and salinity was relatively high (Fig. 3). Axis 1 scores were most highly correlated with distance to the nearest pass to the Gulf of Mexico ( $C \_D i s t$, $r=-0.97)$, salinity at the sampling sites $(r=0.94)$, and the area of continuous seagrass habitat (using $1600 \mathrm{~m}$ radius, LA_SG616, $r=0.91$ ) around each sampling site (Table 1). The linear model used to develop the map of RDA Axis 1 was highly significant (Axis 1 scores $=0.3865489-0.000015\left(C_{-}\right.$Dist $)+0.0165766$ (LA_SG616), $\left.\mathrm{n}=392, F=4682.19, \mathrm{p}<0.0001, \mathrm{r}^{2}=0.96\right)$.
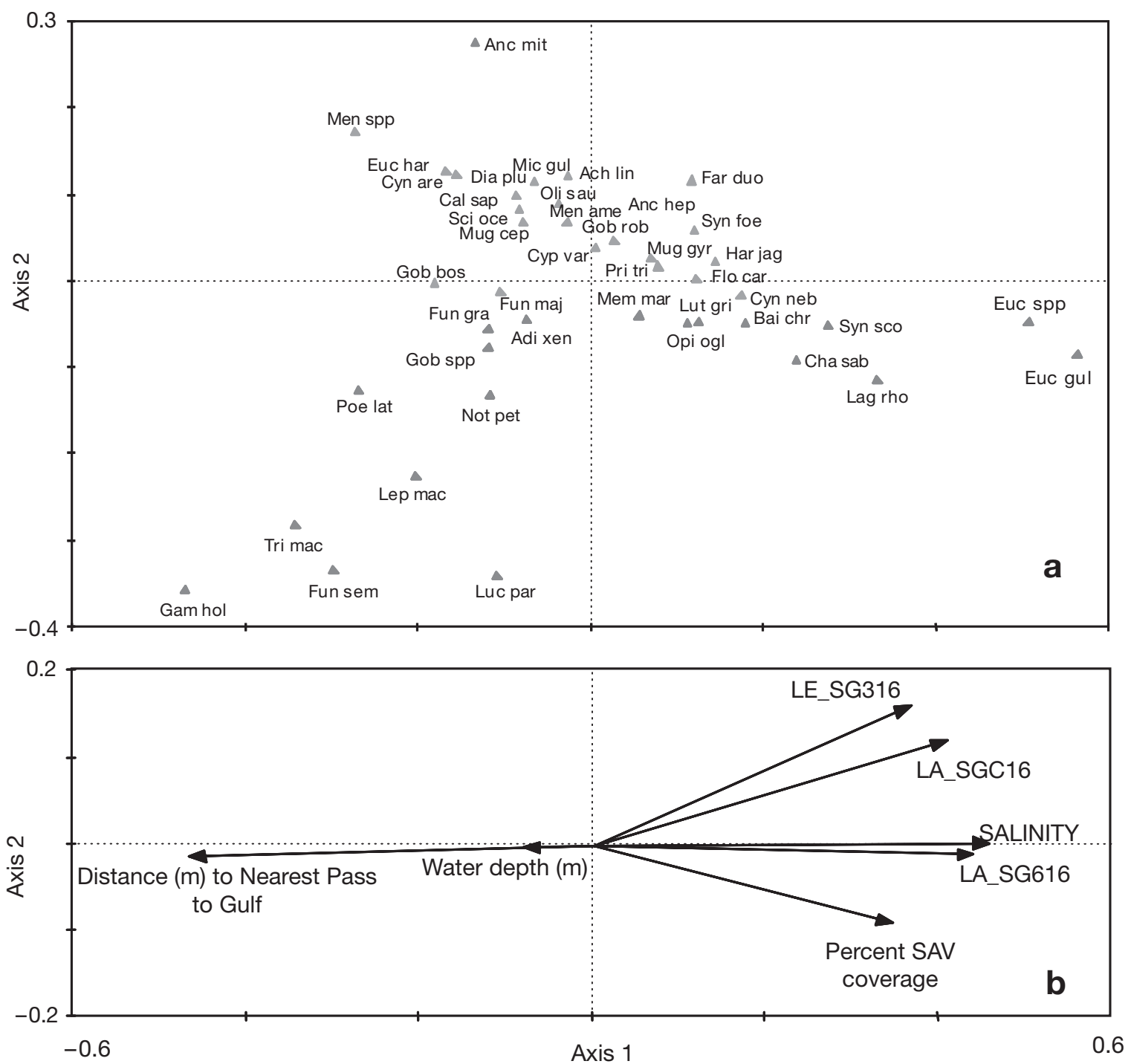

Fig. 3. (a) Redundancy analysis (RDA) ordination diagrams showing most common fish and selected invertebrate species. ( $\Delta$ ) the center of the species' distribution in ordination space; species are labeled using the first 3 letters of the genus and species names (full scientific and common names for all species in Fig. 6). (b) Habitat and environmental variables most closely correlated with the first 4 most important gradients (axes); first 2 RDA axes are shown. Landscape variables most closely correlated with key gradients (RDA axes) were distance $(\mathrm{m})$ to nearest pass to Gulf LA_SG616 = area of continuous seagrass beds, LA_SGC16 = area of patchy and continuous seagrass beds (combined) and LE_SG316 = edge density of discontinuous seagrass beds (1600 m search radius); environmental variables most closely correlated with RDA axes included salinity (ppt), depth (m), and percent cover of submerged aquatic vegetation at sampling site 
Table 1. Final redundancy analysis (RDA) for nekton abundance $(\mathrm{n}=392)$. Eigenvalues indicate relative influence of the 4 main RDA axes. Inter-set correlation of individual habitat and environmental variables with canonical axes are presented. LA_SG616 = area of continuous seagrass $\left(\mathrm{m}^{2}, 1600 \mathrm{~m}\right.$ radius $)$, LA_SGC16 $=$ area of continuous and discontinuous seagrass combined $\left(\mathrm{m}^{2}\right.$, $1600 \mathrm{~m}$ radius), LE_SG316 $=$ edge density $\left(\mathrm{m} \mathrm{km}^{-2}\right)$ of discontinuous seagrass; $\mathrm{SAV}=$ percent coverage of submerged aquatic vegetation

\begin{tabular}{|lrrrr|}
\hline Parameter & Axis 1 & Axis 2 & Axis 3 & Axis 4 \\
\hline Eigenvalues & 0.09 & 0.04 & 0.02 & 0.01 \\
Species-environment correlation & 0.76 & 0.51 & 0.43 & 0.31 \\
Cumulative \% variance & & & & \\
Species data & 9.3 & 13.0 & 14.8 & 15.5 \\
Species-environment relation & 56.8 & 79.4 & 90.0 & 94.6 \\
Habitat and environmental variables: inter-set & correlations with axis \\
Distance (m) to nearest pass & -0.97 & -0.06 & -0.03 & 0.06 \\
Salinity (ppt) & 0.94 & 0.03 & -0.09 & -0.11 \\
LA_SG616 & 0.91 & 0.00 & 0.24 & -0.11 \\
LA_SGC16 & 0.83 & 0.44 & 0.10 & 0.12 \\
LE_SG316 & 0.75 & 0.57 & 0.01 & 0.18 \\
Depth (m) & -0.15 & 0.07 & 0.82 & 0.16 \\
SAV (\% cover) & 0.72 & -0.37 & -0.09 & 0.54 \\
\hline
\end{tabular}

mon across all 4 spatial zones; these included bay anchovy Anchoa mitchilli, unidentified species of the genus Menidia, and unidentified species of the genus Eucinostomus, Fig. 6). Within Zone 1, mean densities of several species often considered marsh-associated (e.g. eastern mosquitofish Gambusia holbrooki, rainwater killifish Lucania parva, and sailfin molly Poecilia latipinna) were at least 1 order of magnitude higher than in the other 3 zones (Fig. 6). Several marshassociated freshwater species (e.g. Seminole killifish Fundulus seminolis - which occurred only in the Peace River, brook silverside Labidesthes sicculus, and least killifish Heterandria formosa) occurred exclusively in this zone. Of the 4 spatial zones, Zone 1 had the highest mean nekton density (5.50 fish per $100 \mathrm{~m}^{2}$ ).
Axis 2 appeared to also be a broad-scale gradient somewhat related to edge density of patchy seagrass beds (1600 m radius, $r=0.57$, Table 1 ) that was highest in the middle of the estuary. Due to the relatively low correlations, we determined that this axis was not strongly represented by any measured variables in the analysis. The third and fourth gradients represented local-scale habitat characteristics and were most highly correlated with water depth (Axis 3, r = 0.81 ) and percent seagrass coverage (Axis $4, \mathrm{r}=0.54$, Table 1).

\section{Spatial structure along RDA Axis 1}

Zone 1 (RDA Axis 1 scores $\leq-0.2$ ), located in the uppermost, riverine areas (Fig. 4), contained sampling sites with the lowest mean salinity, lowest variability in salinity, and somewhat wider depth range compared with the other 3 zones (Table 2). The mean percentage of seagrass coverage estimated at sampling sites in Zone 1 was relatively low, but the ranges and means of dissolved oxygen and temperature were similar to those in the other zones. Relative values of the estuarine landscape structure measurements were similar among the 4 zones regardless of the search radius used. Therefore, we report the results for the $1600 \mathrm{~m}$ radius only (Fig. 5). Estuarine landscape structure in Zone 1 was dominated by salt marsh habitat, and salt marsh area was 3 times higher here than in any other zone. This zone also had fairly low amounts of mangrove habitat and discontinuous seagrass habitat, and almost no continuous seagrass habitat compared with the other 3 zones (Fig. 5). Several taxa were very com-

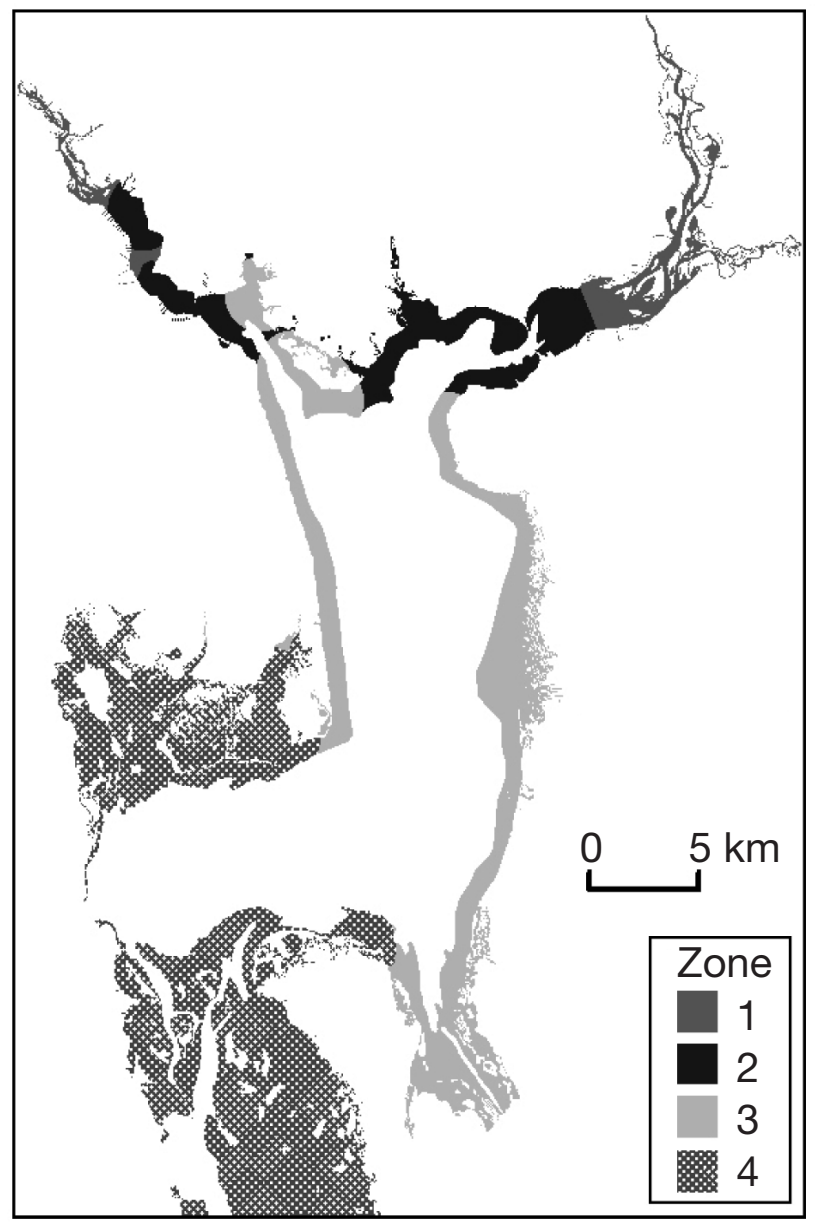

Fig. 4. Community zones based on RDA Axis 1. To identify general spatial trends in the nekton community and estuarine landscape structure, analysis area was divided into 4 zones based on RDA axis scores 
Table 2. Environmental data for the 4 spatial zones across Charlotte Harbor. Data are mean (SD), range

\begin{tabular}{|crccccc|}
\hline & $\mathrm{n}$ & SAV coverage $(\%)$ & Depth $(\mathrm{m})$ & Salinity $(\mathrm{ppt})$ & DO $\left(\mathrm{mg} \mathrm{l} \mathrm{l}^{-1}\right)$ & $T\left({ }^{\circ} \mathrm{C}\right)$ \\
\hline Zone 1 & 131 & $4.3(17.0) 0-100$ & $0.8(0.3) 0.2-1.8$ & $2.8(3.6) 0.1-14.1$ & $6.2(1.5) 3.2-10.7$ & $26.2(2.9) 13.7-33.2$ \\
Zone 2 & 83 & $2.3(9.3) 0-50$ & $0.6(0.3) 0.2-1.5$ & $8.8(5.8) 0.2-20.8$ & $7.1(2.3) 3.5-13.8$ & $25.0(3.9) 14.1-31.7$ \\
Zone 3 & 87 & $33.4(35.6) 0-100$ & $0.7(0.3) 0.2-1.3$ & $19.0(5.8) 4.2-29.1$ & $6.5(2.3) 1.4-11.5$ & $27.3(3.2) 20.1-32.3$ \\
Zone 4 & 91 & $63.7(37.8) 0-100$ & $0.6(0.2) 0.3-1.1$ & $28.6(5.2) 11.7-37.4$ & $7.6(2.7) 2.4-17.0$ & $25.7(4.0) 17.0-31.8$ \\
\hline
\end{tabular}

Mean salinity in Zone 2 (RDA Axis 1 scores -0.19 to 0, Fig. 4) was higher than Zone 1, but lower than Zones 3 and 4 (Table 2). The mean percentage of seagrass coverage within the sampling site was lowest in Zone 2. Zone 2 included the shoreline areas dominated by seawalls adjacent to the towns of Punta Gorda and Port Charlotte, and the mean area of mangrove habitat and mangrove edge densities were also lowest in this zone (Fig. 5). The mean salt marsh area available in Zone 2 was generally less than one-third of that in Zone 1, but relatively higher than in Zones 3 and 4 . Zone 2 also had the lowest area and edge density of salt marshes and mangroves combined, and the lowest area of all habitat types combined. The mean habitat area and edge densities of both discontinuous and continuous seagrass beds in Zone 2 were higher than

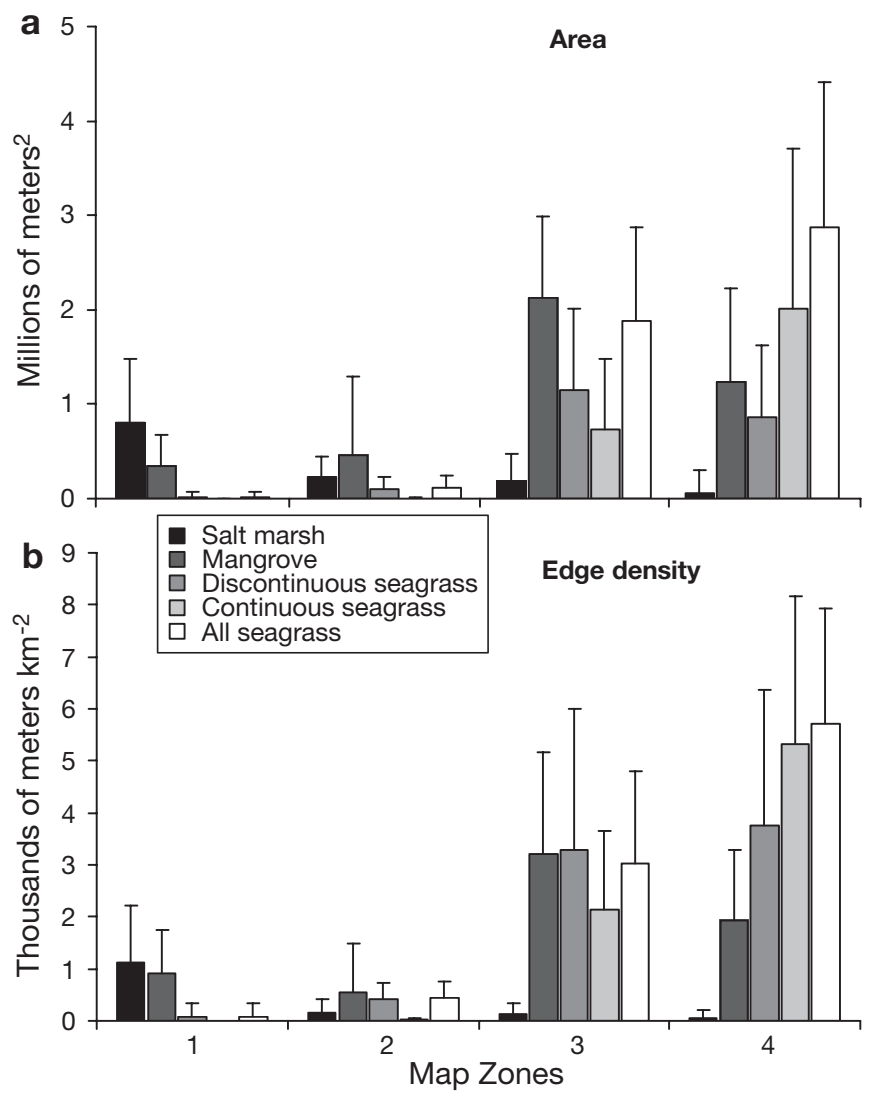

Fig. 5. Measurements of estuarine landscape structure. These had similar relative trends per zone regardless of search radius; therefore, we report only those for the $1600 \mathrm{~m}$ search radius those in Zone 1, but much lower than those in Zones 3 and 4 . The nekton community in this zone was distinguished by relatively high densities of striped killifish Fundulus majalis, tidewater mojarra Eucinostomus harengulus, sheepshead Archosargus probatocephalus, and hardhead catfish Ariopsis felis (Fig. 6). Another unique characteristic of the nekton community in Zone 2 was the low density of rainwater killifish Lucania parva, which had consistently high densities throughout the rest of the analysis area. No species were exclusively found in Zone 2. This zone had the lowest mean nekton density of all the zones (2.67 fish per $100 \mathrm{~m}^{2}$ ).

Zone 3 (RDA scores 0.01 to 0.4 ) included the upper portion of the estuary proper (Fig. 4) and had relatively moderate mean salinity and salinity variability compared to the other zones (Table 2). The mean percent coverage of seagrass was much higher here than in Zones 1 and 2, but lower than in Zone 4. Zone 3 had the highest mean mangrove area and edge density of the 4 zones. Mean discontinuous seagrass edge density in Zone 3 was higher than in Zones 1 and 2, but similar to that in Zone 4 (Fig. 5). Zone 3 also had low mean salt marsh area, and very low mean salt marsh-openwater edge density, because salt marshes in Zone 3 typically occur landward of the mangroves. The nekton community in Zone 3 was distinguished by relatively high mean densities of clown goby Microgobius gulosus and code goby Gobiosoma robustum (Fig. 6). Mean densities of several species, such as pink shrimp Farfantepenaeus duorarum and silver jenny Eucinostomus gula, were relatively high in this zone compared with Zones 1 and 2, but were within 1 order of magnitude of Zone 4 densities. No species were exclusive to Zone 3, and this zone had moderate overall mean densities of all species combined (4.36 fish per $100 \mathrm{~m}^{2}$ ).

Zone 4 (RDA scores $\geq 0.41$ ) represented the lower portion of the estuary (Fig. 4), where the mean salinity was highest and salinity variability was fairly low compared with the other 3 zones (Table 2). Samples in this zone were also characterized by a relatively high mean percentage of seagrass coverage within the sampling sites. Generally, Zone 4 had the highest mean area of continuous seagrass habitat, moderate amounts of mangrove habitat, but little salt marsh habitat around sampling sites compared with those in the other 3 zones (Fig. 5). The nekton community in this zone was 


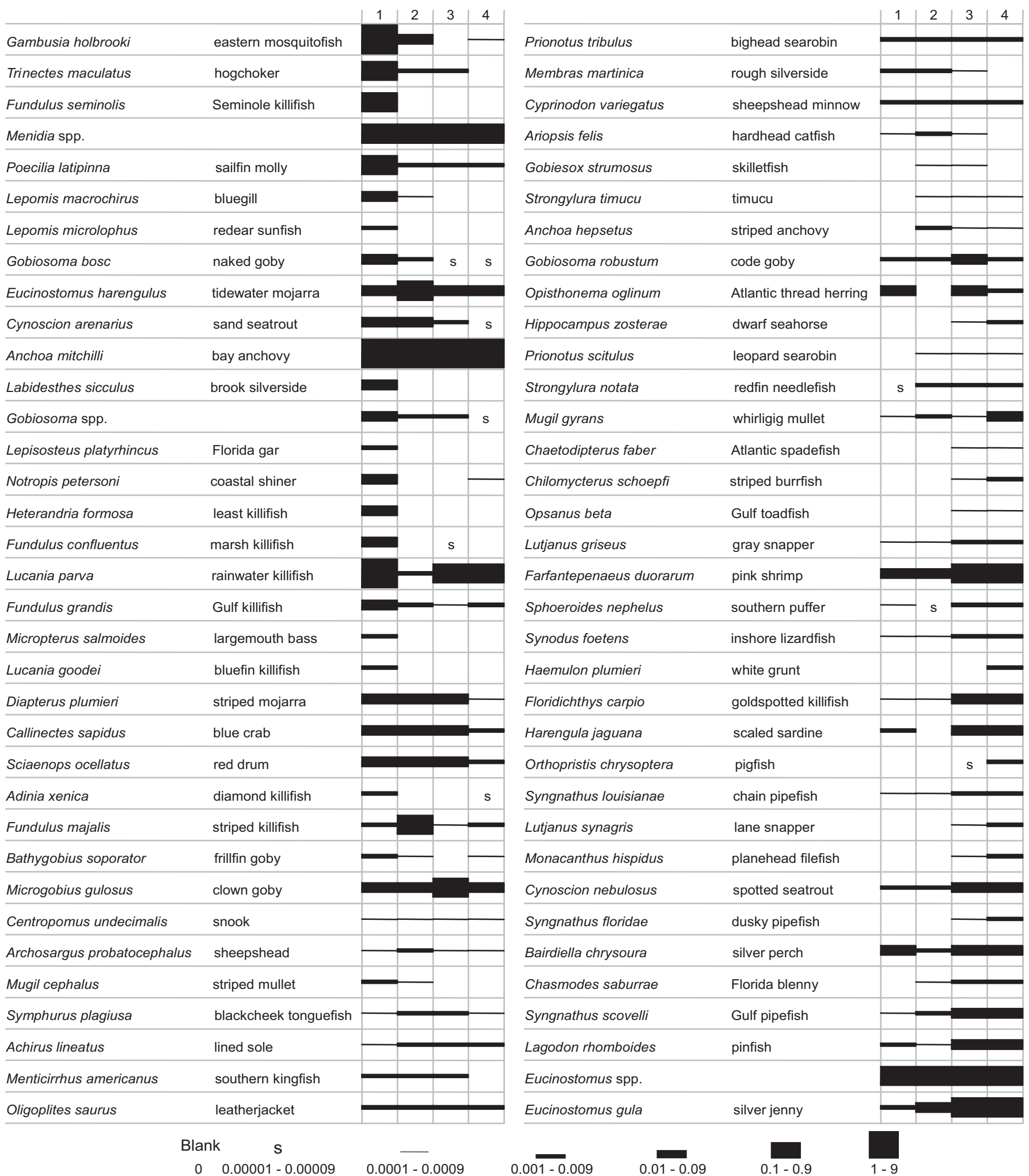

Fig. 6. Mean densities of nekton taxa (no. fish per $100 \mathrm{~m}^{2}$ ) in 4 map zones (see Fig. 4) across Charlotte Harbor, represented by line thickness (order of magnitude scale). Taxa arranged in order from lowest scores on RDA Axis 1 (top, left column) to highest scores 
distinguished by the highest mean densities of several species, including whirligig mullet Mugil gyrans, planehead filefish Monacanthus hispidus, lane snapper Lutjanus synagris, and dwarf seahorse Hippocampus zosterae (Fig. 6). White grunts Haemulon plumieri were collected exclusively in Zone 4 . Zone 4 had moderate overall mean densities of all species combined (4.63 fish per $100 \mathrm{~m}^{2}$ ).

Species richness (number of species) became relatively constant in the 4 zones by the end of the first $2 \mathrm{yr}$ of sampling (1997 to 1998). Therefore, we determined that the level of effort was adequate in sampling the majority of species susceptible to seine capture (Fig. 7). However, several new species were collected in Zone 1 beginning in fall 1999 and in Zone 3 during fall 2000. In the uppermost riverine zone (Zone 1), 4 new species (whirligig mullet Mugil gyrans, southern puffer Sphoeroides nephelus, blackcheek tonguefish Symphurus plagiusa, and bighead searobin Prionotus tribulus) were collected in 4 separate samples taken on a single day (November 11, 1999); 3 additional species (silver jenny Eucinostomus gula, inshore lizardfish Synodus foetens, and chain pipefish Syngnathus louisianae) were collected during the fall of 2000. Because none of these new species are considered freshwater species, they probably shifted their distribution upstream from more southern zones (based on overall density patterns, (Fig. 6). This shift in distribution generally coincided with the beginning of a drought period in the Charlotte Harbor watershed that continued to the end of the sampling period (National Climatic Data Center 2000; available at: www.ncdc.noaa.gov/oa/climate/ research/2000/nov/us_drought.htm). In the fall 2000 sampling period, 5 new species (timucu Strongylura timucu, naked goby Gobiosoma bosc, marsh killifish Fundulus confluentus, whirligig mullet Mugil gyrans, and striped killifish $F$. majalis) were collected in Zone

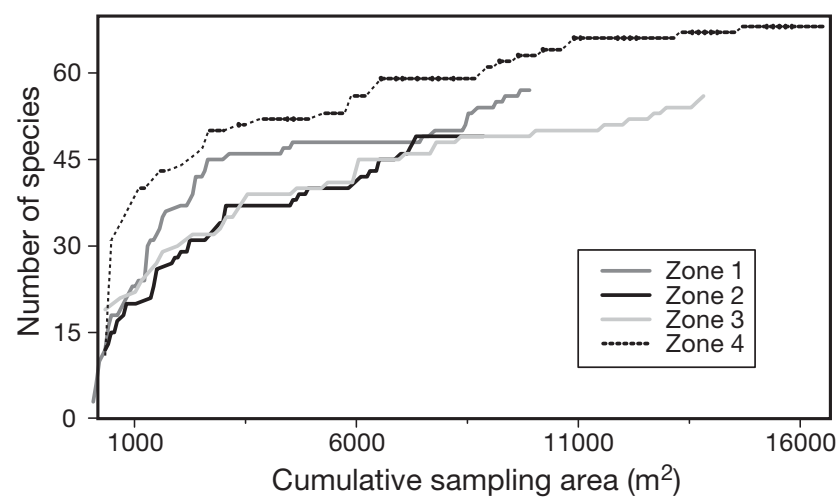

Fig. 7. Cumulative number of species plotted against cumulative area sampled $\left(\mathrm{m}^{2}\right)$ in 4 spatial zones across Charlotte Harbor

3. General density patterns (Fig. 6) suggest that these species could have moved from either upstream or downstream locations into Zone 3. Because the number of species occurring in Zones 1 and 3 continued to increase until the end of the sampling period, we are limited in characterizing general spatial patterns in species richness in these 2 zones. However, the species accumulation curves for Zones 2 and 4 approached asymptotic values: consistent patterns showed highest species richness in Zone 4 throughout the sampling period, whereas species richness in Zone 2 was consistently lower than in Zone 4 and less than or similar to species richness in Zones 1 and 3.

\section{Spatial distribution of juveniles of 5 fishery species}

We found highly significant relationships $(p<0.0001$ for likelihood ratio tests, Table 3) between RDA Axis 1 grid values and frequency of occurrence of juveniles of all 5 fishery species. For all logistic-regression models, the Hosmer-Lemeshow goodness-of-fit test (Hosmer \&

Table 3. Logistic-model summaries describing distribution of 5 selected juveniles of fishery species. Presence = percentage of samples with positive occurrences for each species. Goodness-of-fit statistics for the overall species models are $G$, the likelihood

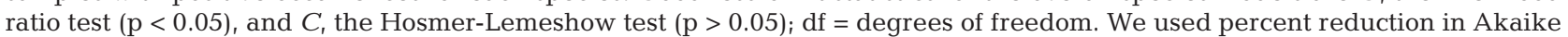
Information Criteria (AIC) from an intercept-only model to the final model as a measure of how well the model fit the data. Each predictor in the model was tested for significance using the Wald statistic $(p<0.05)$

\begin{tabular}{|c|c|c|c|c|c|c|c|c|c|c|c|}
\hline \multirow[t]{2}{*}{ Species } & \multirow{2}{*}{$\begin{array}{l}\text { Presence } \\
(\%)\end{array}$} & \multicolumn{3}{|c|}{ Likelihood ratio } & \multicolumn{3}{|c|}{ Hosmer-Lemeshow } & \multirow{2}{*}{$\begin{array}{l}\text { Drop in } \\
\text { AIC (\%) }\end{array}$} & \multirow{2}{*}{$\begin{array}{l}\text { Significant } \\
\text { variables }\end{array}$} & \multicolumn{2}{|c|}{ Wald statistic } \\
\hline & & $G$ & df & $p$ & C & $\mathrm{df}$ & $\mathrm{p}$ & & & W & $\mathrm{p}$ \\
\hline Sciaenops ocellatus & 19 & 28 & 2 & $<0.0001$ & 8.2 & 8 & 0.4162 & 6 & $\begin{array}{l}\text { RDA Axis } 1 \\
(\text { RDA Axis } 1)^{2}\end{array}$ & $\begin{array}{r}10 \\
9\end{array}$ & $\begin{array}{l}0.0018 \\
0.0026\end{array}$ \\
\hline Cynoscion arenarius & 14 & 33 & 2 & $<0.0001$ & 8.5 & 8 & 0.3829 & 8 & $\begin{array}{l}\text { RDA Axis } 1 \\
(\text { RDA Axis } 1)^{2}\end{array}$ & $\begin{array}{r}12 \\
9\end{array}$ & $\begin{array}{l}0.0003 \\
0.0025\end{array}$ \\
\hline Cynoscion nebulosus & 27 & 82 & 2 & $<0.0001$ & 7.1 & 8 & 0.4560 & 16 & $\begin{array}{l}\text { RDA Axis } 1 \\
(\text { RDA Axis } 1)^{2}\end{array}$ & $\begin{array}{l}53 \\
12\end{array}$ & $\begin{array}{c}<0.0001 \\
0.0005\end{array}$ \\
\hline Lutjanus griseus & 14 & 63 & 1 & $<0.0001$ & 3.5 & 8 & 0.9014 & 19 & RDA Axis 1 & 19 & $<0.0001$ \\
\hline Lutjanus synagris & 7 & 111 & 1 & $<0.0001$ & 2.2 & 8 & 0.9746 & 27 & RDA Axis 1 & 10 & 0.0020 \\
\hline
\end{tabular}


Lemeshow 2000) indicated that the data fit the logistic model ( $p>0.05)$. According to the logistic models, juveniles of both red drum (Sciaenops ocellatus) and sand seatrout Cynoscion arenarius were most likely to occur in the lower portions of the Peace and Myakka rivers (Fig. 8a,b). When predictions were compared with independent observations, however, species occurrence was not well predicted for either red drum $(\rho=0.39, p=0.27)$ or sand seatrout $(\rho=0.53, p=0.11)$. Juveniles of spotted seatrout Cynoscion nebulosus occurred more frequently in mid-estuary sites (Fig. 8c), and independent observations were significantly correlated $(\rho=0.88, p=0.0007$ ) with probabilities of occurrence predicted by the model. The logistic models predicted that gray snapper Lutjanus griseus and lane snapper L. synagris were most likely to occur in areas located near the passes to the Gulf of Mexico (Fig. 8d,e). Gray snapper, however, was one of the more broadly distributed of the 5 species, with a few individuals occurring in the Peace and Myakka rivers. In contrast, all occurrences of lane snapper were constrained to the middle and lower portions of the estuary proper. Independent observations were significantly correlated with predicted probabilities for both gray snapper $(\rho=0.67, p=0.03)$, and lane snapper $(\rho=0.92, p<0.0001)$ indicating that the models predicted occurrence of these species well.

\section{DISCUSSION}

\section{Importance of multiple spatial scales}

The distribution of species is often influenced by patterns and processes operating at a hierarchy of spatial scales (Allen \& Starr 1982), and marine and estuarine nekton communities are no exception (see review by Pittman \& McAlpine 2003). Among the scales considered in our analysis, we found that a broad-scale spatial gradient was most related to nekton community structure. Although the broad-scale processes creating this spatial structure in the nekton community are likely numerous and complex, spatial structure can be used as a surrogate for the processes that create it (Borcard et al. 1992). We described this broad-scale spatial structure using measurements of relative distance and the area of continuous seagrass habitat around the sites
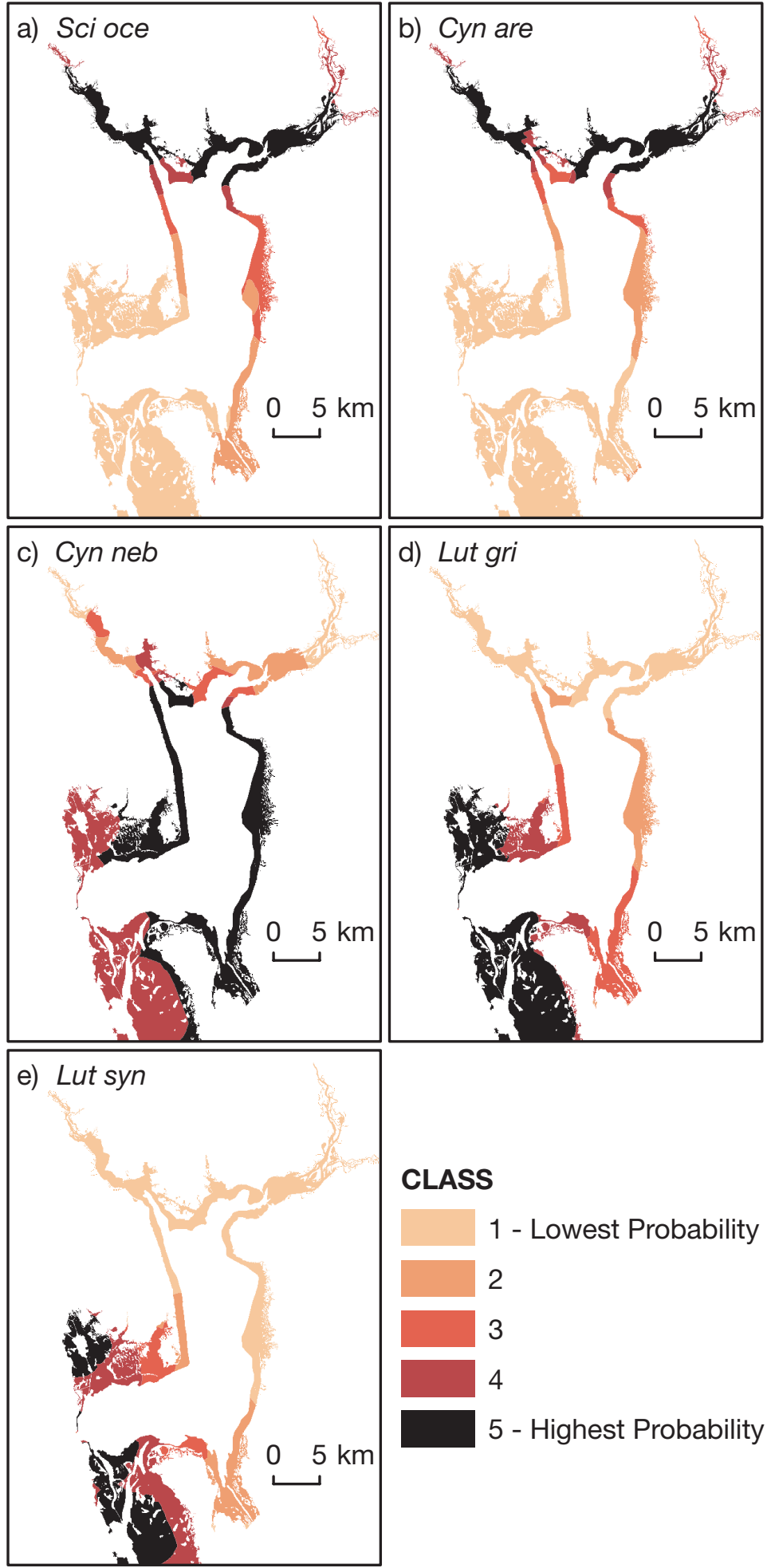

\section{CLASS}
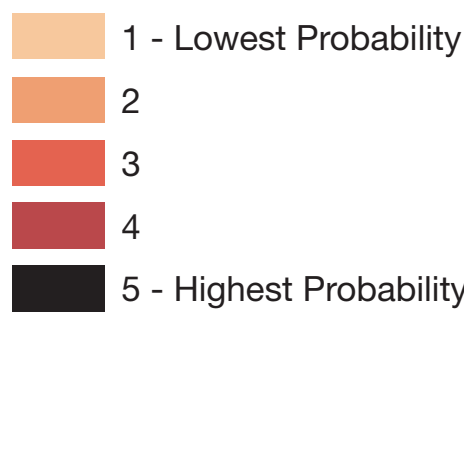

2

3

4

5 - Highest Probability

Fig. 8. Predicted distribution maps for juveniles of 5 fishery species across Charlotte Harbor and lower portions of Peace and Myakka rivers. (a) Red drum Sciaenops ocellatus, (b) sand seatrout Cynoscion arenarius, (c) spotted seatrout C. nebulosus, (d) gray snapper Lutjanus griseus, (e) lane snapper L. synagris. Darker shading indicates relatively higher probability of species occurrence 
(using a $1600 \mathrm{~m}$ radius). For species that often move among multiple habitat types, measuring habitats at a broad scale around sampling sites may be a better indicator of the habitats available to species than measuring only those habitats within the sampling site (see review by Pittman \& McAlpine 2003; for examples see McGarigal \& McComb 1995, Pittman et al. 2004, Seoane et al. 2004). In addition, using habitat structure around sampling sites and spatial location is advantageous in modeling and mapping species distribution because, unlike variables measured only at sample point locations, coastal wetlands or seagrass beds have been comprehensively mapped for many estuaries and coastal areas. Therefore, these comprehensive variables may be used to extrapolate broad-scale nekton species distribution patterns over an entire study area. Nested within this broad spatial structure in the nekton community, however, were important spatial structures and processes operating at finer scales. Finescale gradients (RDA Axes 3 and 4) influencing nekton community structure were only represented by water depth and percent seagrass coverage measured within sample point locations. Further refinement of the spatial community model may benefit from the development of detailed bathymetry or higher resolution spatial data on seagrass habitat distribution covering our study area.

\section{Estuarine landscape structure and nekton community}

Ward et al. (1999) and Pittman et al. (2004) found positive spatial relationships between mapped habitat types (mangroves, salt marshes, and seagrass beds) and nekton community characteristics, such as density and diversity measures, in Australian embayments with little freshwater input (Jervis Bay: 34 to 36 salinity, Holloway et al. 1992; Deception Bay: 20 to 33 salinity, Milford \& Church 1977, S. Pittman pers. comm.), compared with our study area in Charlotte Harbor (0 to 37 salinity). Yet we found spatial coincidence between estuarine landscape structure and nekton community characteristics in Charlotte Harbor, and some of these spatial relationships were similar to those found in Australia. For example, Pittman et al. (2004) found the highest number of species and highest overall nekton density in areas dominated by continuous seagrass, measured at their broadest scale (over a $300 \mathrm{~m}$ radius around sampling sites) in Deception Bay. We also found that the highest number of nekton species coincided spatially with relatively large areas of continuous seagrass measured at our broadest scale (1600 m radius around sites). However, we also found some temporal variability in the number of species, particularly in the riverine areas during a period of drought in the later years of the study. Although highest densities were found in continuous seagrass in Deception Bay (Pittman et al. 2004), we found highest mean nekton density within the Peace and Myakka rivers in areas with little seagrass but extensive salt marsh. The relatively large proportion of marsh-associated nekton species collected in these riverine samples suggest that the high mean nekton densities may have been influenced by relatively large areas of nearby salt marsh habitat. Analogous riverine areas characterized by low salinity and extensive salt marsh were not included in the Pittman et al. (2004) study and may not exist in Deception Bay. Lowest values for nekton densities and the Shannon diversity index were found in areas with little vegetation in Deception Bay. In Charlotte Harbor, we also found the lowest mean nekton densities and relatively low nekton diversity in the spatial zone (Zone 2) with the least area of all habitat types combined. This zone was adjacent to the municipalities of Port Charlotte and Punta Gorda, and the shorelines in this area appear to be the most affected by conversion to seawalls and rubble. In a northern Gulf of Mexico estuary, Peterson et al. (2000) also found lower estuarine nekton abundance and diversity along shorelines altered with bulkheads or rubble than along natural Juncus-Spartina shorelines. Ward et al. (1999) suggested that maps of habitat types may be used as spatial surrogates in selecting sites for overall biodiversity conservation in an Australian embayment. Although our analysis was restricted to nekton taxa, we also found that patterns in estuarine landscape structure, particularly those of continuous seagrass, coincided spatially with patterns in nekton species composition across the 4 zones in the Charlotte Harbor estuary. Additional studies are needed to examine whether spatial patterns between estuarine landscape structure and nekton community characteristics are common across estuaries (with different geomorphology and human influence) and time periods.

\section{Individual species models}

Juveniles of gray snapper Lutjanus griseus and lane snapper L. synagris are often found in seagrass beds (Chester \& Thayer 1990, Nagelkerken et al. 2001), while adults are generally associated with offshore coral reefs or other hard bottom substrates. We found that juveniles of these 2 species occurred most often near the connections to the marine environment where continuous seagrass was abundant and salinity was relatively high. Identification of specific processes creating the distribution patterns of these species was beyond the scope of this paper. However, the higher occurrence of juveniles in this area may be related to 
facilitated settlement of larvae in areas near passes connecting the estuary to the Gulf of Mexico, as suggested for other species that spawn offshore but occur in estuaries as juveniles (e.g. Bell et al. 1988, Hannan \& Williams 1998, Luettich et al. 1999).

Seagrass beds are also considered to be the primary habitat for juveniles of spotted seatrout Cynoscion nebulosus (McMicheal \& Peters 1989, Rooker et al. 1998, Thayer et al. 1999), although they can also be found in high abundance along marsh edges (e.g. Rakocinski et al. 1992) and in unvegetated backwaters (McMicheal \& Peters 1989). The distribution of juveniles of spotted seatrout was centered in the middle of the estuary in seagrass beds in Florida Bay (Thayer et al. 1999) and in mid-estuary salt marshes in a northern Gulf of Mexico estuary (Rakocinski et al. 1992). In Charlotte Harbor, the distribution of these juveniles was also centered in mid-estuary sites characterized by relatively large areas of discontinuous seagrass habitat.

Broad-scale spatial distribution patterns of juveniles of red drum Sciaenops ocellatus vary depending on the geographic location of the estuary under study. The majority of studies have occurred in the northern Gulf of Mexico, where the primary habitat for this species is presumed to be seagrass when present (e.g. Rooker et al. 1998, Stunz et al. 2002), and edges of Spartina alterniflora salt marsh when seagrass is not present in the area (Rakocinski et al. 1992, Stunz et al. 2002). Despite abundant seagrass habitat, however, juveniles of red drum occurred most frequently in low-salinity sites with little to no seagrass in both Charlotte Harbor and Tampa Bay (Peters \& McMicheal 1987), an estuary located $90 \mathrm{~km}$ north of Charlotte Harbor. In both estuuaries, juveniles of red drum were collected near Juncus roemerianus salt marsh habitat, suggesting that they may be using this habitat type. However, many juveniles of red drum in Charlotte Harbor were also collected in the area with the least amount of all habitat types combined and a relatively large proportion of seawall and rubble shorelines. It is unclear whether juveniles of red drum are using remnants of wetland shorelines or an alternate habitat type in this area. Although the logistic model describing the occurrence patterns of red drum was highly significant, this model had difficulty in predicting occurrence. This may have resulted from temporal variability in occurrence patterns related to freshwater inflow, or reduced amounts of potentially important vegetated habitats in the lower portions of the Peace and Myakka Rivers.

Compared with the other species modeled in this analysis, relatively little is known about distribution patterns of juveniles of sand seatrout Cynoscion arenarius. We found distribution patterns of juveniles of this species centered in the lower portions of the
Peace and Myakka rivers, similar to that of red drum. In Charlotte Harbor, Fraser (1997) found that densities of juveniles of sand seatrout increased with decreasing salinity, and abundance of this species was negatively affected during drier conditions. This suggests that the spatial distribution of sand seatrout may have varied temporally with fluctuations in river discharge during the study period. Although the logistic model describing the distribution of this species was highly significant, this temporal variability may have contributed to the reduced predictive capabilities of the model.

\section{Limitations of the study}

Seines could not sample nekton communities directly within wetland habitats, and some samples were collected when the adjacent wetland was inundated at high tide or during high river flow. Consequently, nekton species within wetland habitats were likely underestimated. However, the influence of wetlands on the nekton community often extends beyond the vegetation boundary, because many wetland-associated nekton organisms often use adjacent subtidal areas as well as the vegetated surface (e.g. Rozas et al. 1988, Pittman \& McAlpine 2003). The seines that were deployed along mangrove and salt marsh shorelines did contain a relatively large portion of wetland-associated species. We found that the spatial zones with highest and lowest mean area of salt marsh habitat coincided with highest and lowest mean nekton densities. Had the salt marshes been sampled directly, these patterns might have been more pronounced. In addition, sampling without regard to wetland inundation levels may have contributed to some of the unexplained variability in the RDA, and possibly to low correlations between measurements of wetland landscape structure and the main nekton community gradients (RDA axes).

Although the same gear type was used for all samples in this study, field conditions in the different areas sampled (rivers, shoreline, offshore) required different deployment strategies. Different capture efficiencies among the deployment strategies may have influenced the mean nekton densities reported for each zone. However, the $21 \mathrm{~m}$ seine targeted similar nekton species and size ranges regardless of deployment strategy, and data were still considered comparable (e.g. McMicheal \& Peters 1989, Paperno et al. 2001, Tsou \& Matheson 2002). Potential differences caused by different deployment strategies were minimized by transforming nekton density data into approximate percent composition (chord transform) before RDA. In addition, we based individual species modeling on species presence or absence (not densities), and mean densities for individual nekton species were reported 
on a log scale to emphasize differences of 1 order of magnitude or higher among spatial zones.

The minimum mapping units (MMU) used for the habitat data sets precluded the identification of small habitat patches. This restricted the analysis to describing only broad-scale (e.g. >1 ha) patterns of estuarine landscape structure. This also caused habitat edge density to be underestimated; this was further underestimated due to the level of photointerpretation detail, which influences how meticulously the habitat edges are delineated. However, these limitations may have been reduced, because these measurements were used as relative values in the RDA.

A final limitation is related to spatial autocorrelation. Spatial correlation between species distributions and environmental or habitat variables is often used to predict the distribution of species and communities across landscapes (as in this study). However, spatial autocorrelation in a variable among sites can violate the assumption of independence and increase the probability of committing a Type I error in many statistical tests (Legendre 1993). Therefore, measuring spatial autocorrelation is recommended in future regression analyses. Ordination techniques (e.g. redundancy analysis), however, are not affected by spatial autocorrelation (Legendre \& Legendre 1998).

\section{Application to estuarine conservation and management}

Spatially explicit descriptions of nekton communities and distributions of juveniles of many fishery species can be useful in developing conservation and management plans targeting habitats used by fishery species, as well as ecosystem processes and estuarine biodiversity. Areas of high probability of occurrence of juveniles of fishery species identified in this study may help determine conservation areas and direct management actions that would benefit these fishery species within this particular study area. In addition, high productivity is a defining characteristic of estuaries, and describing areas of relatively high nekton productivity can help to incorporate these areas into efforts to conserve ecosystem processes. Although conservation goals targeting biodiversity should ideally include the entire suite of estuarine biodiversity, the spatial distribution of the entire suite of biodiversity is rarely known across an estuary or embayment. Ward et al. (1999) found that vegetated habitat maps and nekton communities could be used as spatial surrogates for overall biodiversity in conservation planning in an Australian embayment. In the Charlotte Harbor estuary, we found that habitat maps helped to describe and map nekton communities, and these community maps may help to identify sites for conservation that would benefit the suite of nekton taxa in the study area. Conservation goals based on habitats used by juveniles of fishery species, nekton productivity, or biodiversity are not mutually exclusive but may identify similar areas for conservation (Roberts et al. 2001, Halpern 2003). For example, our results suggest that within the areas of high overall nekton productivity located in the lower portions of the Peace and Myakka rivers, 2 juvenile fishery species (red drum Sciaenops ocellatus and sand seatrout Cynoscion arenarius) also have a relatively high likelihood of occurrence. Although our results cover only the fall season, this is an important recruitment time for many nekton species in the Gulf of Mexico. Similar analysis techniques may be applied to additional time periods and spatial extents to examine temporal and broader spatial variability in distribution patterns. Temporal variability in community and species distribution patterns has been observed in many estuaries, Charlotte Harbor included (e.g. Poulakis et al. 2003), so this temporal variability needs to be considered in broad-scale estuarine conservation planning and ecosystem management.

Acknowledgements. We are grateful to the Florida Fish and Wildlife Research Institute's Fisheries Independent Monitoring Program for collecting the field data. This sampling program is partially supported by the US Fish and Wildlife Service (Sport Fish Restoration Grant F-43). Our appreciation also goes to the Southwest Florida Water Management District for use of their land use/land cover and seagrass GIS coverages. In addition, we greatly appreciate support by senior staff (H. Norris, G. Henderson, and K. O'Keife) and the entire Center for Spatial Analysis team at FWRI (partially supported by the US Fish and Wildlife Service, Sport Fish Restoration Grant F-66). The National Marine Fisheries ServiceMARFIN program (Grant Number NA17FF2866) and a State Wildlife Grant (Grant Number T312) funded portions of this analysis. The State of Florida provided matching funds. Thanks to M. Christman for providing statistical advice regarding logistic models and P. Kubilis for providing S-Plus programming support for Fig. 6. This manuscript benefited from valuable comments from M. Greenwood, E. Matheson, R. Flamm, and 3 anonymous reviewers.

\section{LITERATURE CITED}

Allen TFH, Starr TB (1982) Hierarchy-perspective for ecological complexity. University of Chicago Press, Chicago

Araujo MB, Densham PJ, Williams PH (2004) Representing species in reserves from patterns of assemblage diversity. J Biogeogr 31:1037-1050

Beck MW, Heck KL, Able KW, Childers DL and 9 others (2001) The identification, conservation, and management of estuarine and marine nurseries for fish and invertebrates. BioScience 51:633-641

Bell JD, Steffe AS, Westoby M (1988) Location of seagrass beds in estuaries: effects on associated fish and decapods. J Exp Mar Biol Ecol 122:127-146

Borcard D, Legendre P (1994) Environmental control and spatial structure in ecological communities: an example 
using oribatid mites (Acarti, Oribatei). Environ Ecol Stat 1: 37-61

Borcard D, Legendre P, Drapeau P (1992) Partialling out the spatial component of ecological variation. Ecology 73: 1045-1055

Breininger D, Larson V, Duncan B, Smith R, Oddy D, Goodchild M (1995) Landscape patterns of Florida scrub jay habitat use and demographic success. Conserv Biol 9: 1442-1453

Brown SK, Buja KR, Jury SH, Monaco ME (2000) Habitat suitability index models for eight fish and invertebrate species in Casco and Sheepscot Bays, Maine. N Am J Fish Manag 20:408-435

Carbonell A, Palmer M, Abelló P, Torres P, Alemany R, Gil de Sola L (2003) Mesoscale geographical patterns in the distribution of pandalid shrimps Plesionika spp. in the Western Mediterranean. Mar Ecol Prog Ser 247:151-158

Chester AJ, Thayer GW (1990) Distribution of spotted seatrout (Cynoscion nebulosus) and grey snapper (Lutjanus griseus) juveniles in seagrass habitats of western Florida Bay. Bull Mar Sci 46:345-357

Deegan LA, Finn JT, Ayvazian SG, Ryder-Kieffer CA, Buonaccorsi J (1997) Development and validation of an estuarine biotic integrity index. Estuaries 20:601-617

Dicks E, Lo HC (1990) Evaluation of thematic map accuracy in a landuse and landcover mapping program. Photogramm Eng Remote Sensing 56:1247-1252

Fraser TH (1997) Abundance, seasonality, community indices, trends and relationships with physicochemical factors of trawled fish in upper Charlotte Harbor, Florida. Bull Mar Sci 60:739-763

FDOT (1999) Florida land use, cover and forms classification system handbook, 3rd edn. Florida Department of Transportation, Maps and Publications Office, Tallahassee, FL

Guisan A, Zimmermann NE (2000) Predictive habitat distribution models in ecology. Ecol Model 135:147-186

Guisan A, Weiss SB, Weiss AD (1999) GLM versus CCA spatial modeling of plant species distribution. Plant Ecol 143:107-122

Halpern BS (2003) The impact of marine reserves: do reserves work and does reserve size matter? Ecol Appl 13:S117-S137

Hannan JC, Williams RJ (1998) Recruitment of juvenile marine fishes to seagrass habitat in a temperate Australian estuary. Estuaries 21:29-51

Harris BA, Haddad KD, Steidinger KA, Huff JA (1983) Assessment of fisheries habitat: Charlotte Harbor and Lake Worth, Florida. Final Report, Florida Department of Natural Resources, St. Petersburg

Holloway PE, Symonds G, Nunes Vaz R (1992) Observations of circulation and exchange processes in Jervis Bay, New South Wales. Aust J Mar Freshw Res 43:1487-1515

Hosmer DW, Lemeshow S (2000) Applied logistic regression, 2nd edn. John Wiley \& Sons, New York

Hovel KA, Fonseca MS (2005) Influence of seagrass landscape structure on the juvenile blue crab habitat-survival function. Mar Ecol Prog Ser 300:179-191

Hovel KA, Lipcius RN (2001) Habitat fragmentation in a seagrass landscape: patch size and complexity control blue crab survival. Ecology 82:1814-1829

Irlandi EA, Crawford MK (1997) Habitat linkages: the effect of intertidal saltmarshes and adjacent subtidal habitats on abundance, movement, and growth of an estuarine fish. Oecologia 110:222-230

Jensen OP, Seppelt R, Miller TJ, Bauer LJ (2005) Winter distribution of blue crab Callinectes sapidus in Chesapeake Bay: application and cross-validation of a two-stage generalized additive model. Mar Ecol Prog Ser 299:239-255
Kneib RT (2003) Bioenergetic and landscape considerations for scaling expectations of nekton production from intertidal marshes. Mar Ecol Prog Ser 264:279-296

Legendre P (1993) Spatial autocorrelation: trouble or new paradigm? Ecology 74:1659-1673

Legendre P, Gallagher ED (2001) Ecologically meaningful transformations for ordination of species data. Oecologia 129:271-280

Legendre P, Legendre L (1998) Numerical ecology, 2nd English edn. Elsevier, Amstersdam

Luettich RA, Hench JL, Fulcher CW, Werner FE, Blanton BO, Churchill JH (1999) Barotropic tidal and wind driven larvae transport in the vicinity of a barrier island inlet. Fish Oceanogr 8 (Suppl 2):190-209

Margules CR, Pressey RL (2000) Systematic conservation planning. Nature 405:243-253

McGarigal K, McComb WC (1995) Relationships between landscape structure and breeding birds in the Oregon coast range. Ecol Monogr 65:235-260

McMicheal RH, Peters KM (1989) Early life history of spotted seatrout, Cynoscion nebulosus (Pisces: Sciaenidae), in Tampa Bay, Florida. Estuaries 12:98-110

McNeill SE, Fairweather PG (1993) Single large or several small marine reserves? An experimental approach with seagrass fauna. J Biogeogr 20(4):429-440

Milford SN, Church JA (1977) Simplified circulation and mixing models of Moreton Bay, Queensland. Aust J Mar Freshw Res 28:23-34

Minello TJ, Able KW, Weinstein MP, Hays CG (2003) Salt marshes as nurseries for nekton: testing hypotheses on density, growth and survival through meta-analysis. Mar Ecol Prog Ser 246:39-59

Murphy DD, Noon BR (1992) Integrating scientific methods with habitat conservation planning: reserve design for northern spotted owls. Ecol Appl 2:3-17

Nagelkerken I, Kleijnen S, Klop T, van den Brand RA, Cocheret de la Morinicre CJ, van der Velde G (2001) Dependence of Caribbean reef fishes on mangroves and seagrass beds as nursery habitats: a comparison of fish faunas between bays with and without mangroves/seagrass beds. Mar Ecol Prog Ser 214:225-235

Olden JD, Jackson DA, Peres-Neto R (2002) Predictive models of fish species distribution: a note on proper validation and chance predictions. Trans Am Fish Soc 131: 329-336

Paperno R, Mille KJ, Kadison E (2001) Patterns in species composition of fish and selected invertebrate assemblages in estuarine subregions near Ponce de Leon Inlet, Florida. Estuar Coast Shelf Sci 52:117-130

Parrish JD (1989) Fish communities of interacting shallowwater habitats in tropical oceanic regions. Mar Ecol Prog Ser 58:143-160

Pérez-Castañeda R, Defeo O (2004) Spatial distribution and structure along ecological gradients: peneaid shrimps in a tropical estuarine habitat of Mexico. Mar Ecol Prog Ser 273:173-185

Peters KM, McMicheal RH (1987) Early life history of the red drum, Sciaenops ocellatus (Pisces: Sciaenidae), in Tampa Bay, Florida. Estuaries 10:92-107

Peterson MS, Comyns BH, Hendon JR, Bond PJ, Duff GA (2000) Habitat use by early life-history stages of fishes and crustaceans along a changing estuarine landscape: differences between natural and altered shoreline sites. Wetlands Ecol Manag 8:209-219

Pittman SJ, McAlpine CA (2003) Movement of marine fish and decapod crustaceans: process, theory, and application. Adv Mar Biol 44:205-294 
Pittman SJ, McAlpine CA, Pittman KM (2004) Linking fish and prawns to their environment: a hierarchical landscape approach. Mar Ecol Prog Ser 283:233-254

Poulakis GR, Blewett DA, Mitchell ME (2003) The effects of season and proximity to fringing mangroves on seagrassassociated fish communities in Charlotte Harbor, Florida. Gulf Mex Sci 2:171-184

Rakocinski CF, Baltz DM, Fleeger JF (1992) Correspondence between environmental gradients and the community structure of marsh-edge fishes in a Louisiana estuary. Mar Ecol Prog Ser 80:135-148

Roberts CM, Bohnsack JA, Gell F, Hawkins JP, Goodridge R (2001) Effects of marine reserves on adjacent fisheries. Science 294:1920-1923

Roberts CM, Andelman S, Branch G, Bustamante RH and 10 others (2003) Ecological criteria for evaluating candidate sites for marine reserves. Ecol Appl 13:S199-S214

Rooker JR, Holt SA, Soto MA, Holt GJ (1998) Postsettlement patterns of habitat use by sciaenid fishes in subtropical seagrass meadows. Estuaries 21:318-327

Rozas LP, McIvor CC, Odum WE (1988) Intertidal rivulets and creekbanks: corridors between tidal creeks and marshes. Mar Ecol Prog Ser 47:303-307

Seoane J, Bustamante J, Diaz-Delgado R (2004) Competing roles for landscape, vegetation, topography and climate in predictive models of bird distribution. Ecol Model 171:209-222

Skilleter GA, Olds A, Loneragan NR, Zharikov Y (2005) The value of patches of intertidal seagrass to prawns depends on their proximity to mangroves. Mar Biol 147:353-365

Editorial responsibility: Kenneth Heck Jr. (Contributing Editor), Dauphin Island, Alabama, USA
Smith TM, Hindell JS (2005) Assessing effects of diel period, gear selectivity and predation on patterns of microhabitat use by fish in a mangrove dominated system in SE Australia. Mar Ecol Prog Ser 294:257-270

Stunz GW, Minello TJ, Levin PS (2002) A comparison of early juvenile red drum densities among various habitat types in Galveston Bay, Texas. Estuaries 25:76-85

ter Braak CJF (1995) Ordination. In: Jongman RHG, ter Braak CJF, van Tongeren OFR (eds) Data analysis in community and landscape ecology. Cambridge University Press, Wageningen, p 91-173

ter Braak CJF, Smilauer P (2002) CANOCO reference manual and CanoDraw for Windows user's guide: software for canonical community ordination (version 4.5). Microcomputer Power, Ithaca, New York

ter Braak CJF, Verdonschot PFM (1995) Canonical correspondence analysis and related multivariate methods in aquatic ecology. Aquat Sci 57:255-289

Thayer GW, Powell AB, Hoss DE (1999) Composition of larval, juvenile, and small adult fishes relative to changes in environmental conditions in Florida Bay. Estuaries 22:518-533

Tsou TS, Matheson RE (2002) Seasonal changes in the nekton community of the Suwannee River estuary and the potential impacts of freshwater withdrawal. Estuaries 25: $1372-1381$

Ward TJ, Vanderklift MA, Nicholls AO, Kenchington RA (1999) Selecting marine reserves using habitats and species assemblages as surrogates for biological diversity. Ecol Appl 9:691-698

Submitted: October 13, 2005; Accepted: June 7, 2006 Proofs received from author(s): January 12, 2007 